\title{
LISTY RUSKIE KRÓLA ZYGMUNTA II AUGUSTA DO MIKOŁAJA RADZIWIŁŁA RUDEGO Z LAT 1568-1571 ZE ZBIORÓW MUZEUM KONSTANTEGO ŚWIDZIŃSKIEGO (BIBLIOTEKA ORDYNACJI KRASIŃSKICH)
}

Rafał Jaworski

Uniwersytet Jana Kochanowskiego w Kielcach, Filia w Piotrkowie Trybunalskim

\author{
ABSTRACT \\ KING SIGISMUND II AUGUSTUS' RUSSIAN LETTERS TO MIKOŁAJ \\ "THE RED" RADZIWIŁŁ FROM THE PERIOD OF 1568-1571 IN THE \\ COLLECTIONS OF KONSTANTY ŚWIDZIŃSKI MUSEUM (KRASIŃSKI \\ LIBRARY)
}

The correspondence between the king Sigismund II Augustus and the Radziwiłł family is one of the main sources of research on the political history of the Grand Duchy of Lithuania and Polish-Lithuanian relationships in the second half of $16^{\text {th }}$ century. Five Russian letters of the last member of the Jagiellonian Dynasty to Mikołaj "the Red" Radziwiłl from the period of 1568-1571 are the subject of this article. The original documents were destroyed in 1944 but the information about their content is available owing to the abridged versions printed in 1876 by W. Chomętowski. The abridgements didn't come into scientific circulation. There is also Stanisław Bodniak's translation of one of the letters (24 ${ }^{\text {th }}$ March 1571, Warsaw). The abridgements and the translation are published in the article, which also contains an attempt to explain in what way the letters from the Nesvizh Archive came to the collection of the Krasiński Library (Konstanty Świdziński Museum). The question of the bilingual correspondence between the king and the Radziwiłł family is also partially discussed.

Key words: Sigismund II Augustus, Radziwiłł family, correspondence.

Słowa kluczowe: Zygmunt II August, Radziwiłłowie, korespondencja. 
Listy wymieniane między ostatnim Jagiellonem na polskim tronie a przedstawicielami domu Radziwiłłów są bezsprzecznie ważnym, a dla wielu zagadnień wręcz niezastąpionym, źródłem do badań nad dziejami politycznymi Wielkiego Księstwa Litewskiego w drugiej połowie XVI wieku. Nie dziwi więc, że korespondencja ta już u zarania nowoczesnej historiografii budziła zainteresowanie badaczy, a ich tradycja edytorska ma długą, bo przeszło stuletnią metrykę, która sama winna się stać przedmiotem naukowej refleksji ${ }^{1}$. Przyjęte przez ówczesnych wydawców zasady edytorskie znacznie odbiegają jednak od współczesnych standardów przyjętych dla tego typu publikacji. Ukazanie się w 1998 roku nowej edycji, w założeniu stanowiącej publikację korpusu listów Zygmunta Augusta do Radziwiłłów², spotkało się więc z dużym zainteresowaniem środowiska badaczy i doczekało dwóch obszernych artykułów recenzyjnych ${ }^{3}$. Autorzy obu recenzji odnieśli się krytycznie do wydawnictwa reklamowanego jako: „pierwsza, najpełniejsza, nowocześnie opracowana edycja 365 listów ostatniego Jagiellona"4. Podkreślano przede wszystkim, że publikowane teksty nie podają w sposób możliwie najwierniejszy tekstów źródłowych ${ }^{5}$. Zwracano również uwagę, że nie przeprowadzono, niezbędnej przy realizacji takiego przedsięwzięcia, szerokiej kwerendy w poszukiwaniu nieznanych dotychczas listów ${ }^{6}$. Dowodnym świadectwem zaniedbania tego ostatniego obowiązku jest zestawiony przez Marka Janickiego i Rafała Jaworskiego Aneks zamieszczony na końcu ich artykułu recenzyjnego. Jak zaznaczyli, był on „w znacznej mierze efektem wyrywkowej kwerendy opartej na ogólnie dostępnych inwentarzach i katalogach". Aneks podzielony jest na trzy części. W pierwszej znalazł się spis 33 listów (18 listów polskich, 11 listów ruskich, 3 listy łacińskie oraz 1 list w języku nieznanym) nieuwzględnionych w omawianej edycji i pozostającej jako inedita. Zestawienie to zostało uzupełnione aneksem opublikowanym w artykule Rafała Jaworskiego w 2002 roku, który

1 J.U. Niemcewicz, Zbiór pamiętników historycznych o dawnej Polszczę, t. 1, Warszawa 1822, s. 395-484; S.A. Lachowicz, Listy oryginalne Zygmunta Augusta do Mikołaja Radziwitta Czarnego, Wilno 1842; idem, Materialy historyczne spisane z autentyków Biblioteki Cesarskiej w Petersburgu, „Atheneum” 1842, R. 5, nr 1, s. 28-54; M. Balińsk i, Pamiętniki o królowej Barbarze żonie Zygmunta Augusta [w:] idem, Pisma historyczne, t. 1-2, Wilno 1843; idem, Dopetnienie pamiętników o królowej Barbarze [w:] idem, Pisma historyczne, Wilno 1856; A. Przezdziecki, Jagiellonki polskie w XVI wieku, t. 1, Kraków 1868; F. Pułaski, Nieznane listy Barbary Radziwitłówny do Mikołaja Radziwilta Rudego i do Zygmunta Augusta, Warszawa 1906.

2 Listy króla Zygmunta Augusta do Radziwiltów, oprac., wstęp i komentarze I. Kaniewska, Kraków 1998, s. 648 (dalej: Listy).

3 M. Janicki, R. Jaworski, Nad nowa edycja listów króla Zygmunta Augusta, „Przegląd Historyczny” 1999, R. 90, z. 3, s. 347-364; H. Lu lew ic z, Daremny trud edytora? Uwagi na marginesie edycji korespondencji ostatniego Jagiellona, „Odrodzenie i Reformacja w Polsce” 2000, R. 44, s. 177-185.

4 Cytat zaczerpnięty z informacji umieszczonej na tylnej karcie okładki edycji.

5 W obu recenzjach zauważono, że podstawą wydawniczą w zdecydowanej większości przypadków nie były (jak deklarowano) zachowane oryginały listów lub ich kopie, lecz wcześniejsze, dalekie od poprawności, poddane carskiej cenzurze edycje XIX-wieczne (M. Janicki, R. Jaworski, op. cit., passim, H. Lulewicz, Daremny trud edytora?, s. 178-181).

${ }^{6}$ Pomijam w tym miejscu jakość komentarza oraz przypisów (zob. M. Janicki, R. Jaworski, op. cit., passim; H. Lulewic z, Daremny trud edytora?, s. 180-182). 
wymienia 8 nowych nieznanych listów (1 w języku polskim i 7 listów ruskich) 7 . W sumie w obu aneksach zidentyfikowano 41 listów ineditów, czyli ponad 10\% liczby listów ogłoszonych w edycji Ireny Kaniewskiej.

W części drugiej Aneksu zestawiono 25 listów wydanych we wspomnianej edycji na podstawie edycji Michała Balińskiego, bez sięgnięcia po oryginały zachowane w zbiorach petersburskiej Rosyjskiej Biblioteki Narodowej (dawniej: Cesarska Biblioteka Publiczna, potem Biblioteka Publiczna im. Sałtykowa-Szczedrina). Tworzą one odrębny poszyt (sygn. 62) w zespole (fondzie) „Zbiór autografów P.P. Dubrowskiego", który zawiera oryginały listów monarszych z lat $1535-1585^{8}$. Tom ten jest dostępny w Polsce od 1992 roku w formie mikrofilmu przechowywanego w Bibliotece Narodowej. Jeśli dodamy do tego jeszcze korespondencję, którą - wbrew deklaracji - reedytowano ze starych edycji, oczywistym postulatem staje się potrzeba nowej całościowej edycji korespondencji Zygmunta Augusta9.

Niewątpliwą zasługą publikacji z 1998 roku jest pobudzenie zainteresowania relacjami ostatniego Jagiellona z Radziwiłłami oraz ich korespondencją ${ }^{10}$.Z czasem wydano również drukiem część dokumentów wykazanych w zestawieniach ineditów. W 2003 roku ogłoszono siedem listów ruskich Zygmunta Augusta do Mikołaja „Rudego” z lat 1550-1571 ${ }^{11}$. Cztery listy polskie skierowane do Mikołaja Radziwiłła „Rudego” znalazły się w edycji Kazimierza Rymuta ${ }^{12}$. Pochodziły one ze wspomnianego poszytu ze zbiorów Dubrowskiego. Osiem lat później Marek Ferenc opublikował pozostałych 15 listów polskich pochodzących z tegoż poszytu ${ }^{13}$.

W przywoływanym już artykule recenzyjnym Marek Janicki i Rafał Jaworski wykazali również niezachowane listy Zygmunta Augusta do Radziwiłłów, co do których nasza wiedza ogranicza się nierzadko do konstatacji faktu ich istnienia w przeszłości. Ten nader skromny wykaz, bo obejmujący jedynie 10 listów, umieszczono w trzeciej części przywoływanego tu już kilkakrotnie $A n e k s u^{14}$. Intencje, jakie przyświecały autorom w opracowaniu tego zestawienia, wyjaśnia przypis: „Możliwie pełne ich zestawienie pozwoli lepiej zorientować się w kręgu adresatów, częstotliwości ekspedycji,

7 R. Jaw or ski, Nieznana korespondencja króla Zygmunta Augusta z Mikołajem Radziwitlem Rudym i Ostafim Wolłowiczem z lat 1550-1571 ze zbiorów Biblioteki Czartoryskich, „Studia Źródłoznawcze” 2003, t. 41 , s. 108.

8 J. Gancarson, Polonica w Zbiorze Autografów Piotra Dubrowskiego (Fond 971) w Rosyjskiej Bibliotece Narodowej w St. Petersburgu, „Teki Sejmowe” 2011, t. 2, s. 7-47.

9 Raczej trudno mówić o postulowanym przez H. Lulewicza drugim poprawionym wydaniu, „w którym wszelkie uchybienia zostaną usunięte. W ten sposób trud edytora włożony w przygotowanie niniejszego tomu nie poszedłby na marne" (Daremny trud edytora?, s. 185).

10 Przykładowo: R. Ragauskienè, A. Ragauskas, Barboros Radvilaités laiškai Žygimantui Augustui ir kitiems : studija apie XVI a. Lietuvos Didžiosios kunigaikštystès moteru korespondencija, Vilnius 2001.

11 R. Jaworski, Nieznana korespondencja..., s. 91-108. W Aneksie I odpowiednio nr 11, 12, $13,15,29,31,32$. Piszący te słowa przygotowuje krytyczną edycję korpusu listów polskich Barbary Radziwiłłówny.

12 Listy polskie XVI wieku, t. 2, red. K. Rymut, Kraków 2001, s. 54-55. W Aneksie I nr 5, 6, 9, 10.

13 M. Ferenc, Listy polskie króla Zygmunta Augusta do Mikołaja Radziwilta ,Rudego” z lat 1548 1556, „Prace Historyczne” 2009, z. 136, passim. W Aneksie I nr 3, 4, 7, 14, 17-27.

14 M. Janicki, R. Jaworski, op. cit., s. 364. 
a także wymiany listów. Nasz krótki i oczywiście niepełny wykaz nie uwzględnia wzmianek o korespondencji w samych listach"15. Większość z nich, jak się wydawało, przepadła bezpowrotnie podczas II wojny światowej. Szczęśliwie okazało się jednak, że w przypadku kilku listów możemy naszą wiedzę znacznie poszerzyć, a w przypadku jednego - podać treść (co prawda w formie thumaczenia).

We wspomnianym Aneksie III (Niezachowane listy Zygmunta Augusta do Radziwiłtów) za katalogiem rękopisów ze zbiorów warszawskiej Biblioteki Ordynacji Krasińskich autorstwa Franciszka Pułaskiego ${ }^{16}$ podano osiem listów skierowanych do:

- Barbary Radziwiłłówny ([Niepołomice], 14 sierpnia 1548 r.);

- Mikołaja Radziwiłła „Rudego” ([Warszawa], 20 października 1568 r.; [Warszawa], 25 lipca 1570 r.; [Warszawa], 15 września 1570 r.; [Warszawa], 24 marca 1571 r.; [Warszawa], 16 maja 1571 r.; [Warszawa], 5 września 1571 r.);

- Mikołaja Krzysztofa Radziwiłła ([Warszawa], 1 października 1571 r.).

Listy te oprawiono wspólnie z innymi listami królewskimi w jeden poszyt, któremu nadano sygnaturę rkps 4001 (w katalogu Pułaskiego poz. 206) ${ }^{17}$. Miejsca wystawienia listów (niepodane $\mathrm{w}$ katalogu) ustalono na podstawie itinerarium ostatniego Jagiellona zestawionego przez Antoniego Gąsiorowskiego ${ }^{18}$.

Informacje podane przez Pułaskiego można zweryfikować oraz znacznie uzupełnić na podstawie o blisko cztery dekady wcześniejszego artykułu Władysława Chomętowskiego z 1876 roku. Ten historyk i edytor źródeł omówił w nim „,nabyte niedawno do Biblioteki Ordynacji Krasińskich oryginalne dokumenta w języku ruskim z archiwum Radziwiłłowskiego" pochodzące ze zbiorów Konstantego Świdzińskiego (1793-1855) ${ }^{19}$.

Konstanty Świdziński w zgodnej opinii współczesnych, potwierdzonej zachowanymi szczęśliwie do naszych czasów inwentarzami, zgromadził niezwykle obszerne zbiory, na które składały się, obok rękopisów, również starodruki oraz bogata kolekcja zabytków sztuki i świadectw kultury materialnej. Kolekcjoner nosił się z zamysłem stworzenia ogólnie dostępnego muzeum, gdzie znalazłyby się jego zbiory. Ostatecznie zapisem testamentalnym przekazał je Ordynacji Myszkowskiej Aleksandra Wielopolskiego, z zastrzeżeniem, że ze zbiorów tych utworzone zostanie odrębne Muzeum Polskie im. Świdzińskich. Kolejne lata przyniosły powolne scalanie rozproszonych dotychczas $\mathrm{w}$ trzech zaborach zbiorów $\mathrm{w}$ specjalnie $\mathrm{w}$ tym

15 Ibidem, s. 364, przyp. 62.

16 F. Pułas ki, Opis 815 rękopisów Biblioteki Ordynacji Krasińskich, Warszawa 1915, s. 168: Pisma królewskie Jadwigi, Władysława Jagietly, Kazimierza Jagiellończyka, Aleksandra, Zygmunta I, Bony i Zygmunta Augusta 1395-1572. Kodeks papierowy XIV-XVI w., zawiera dokumentów 92 w uktadzie ściśle chronologicznym.

17 M. Janicki, R. Jaworski, op. cit., s. 364.

18 Ibidem, s. 364, przyp. 65; A. Gąsiorow ski, Itineraria dwu ostatnich Jagiellonów, „Studia Historyczne" 1973, R. 16, z. 2, s. 149-275.

19 W. Chomętowski, Rękopisma z Archiwum Radziwiltowskiego znajdujące się w Bibliotece Hrabiów Krasińskich z Muzeum Konstantego Świdzińskiego [w:] Korespondencye Jana Karola Chodkiewicza: poprzedzone opisem rękopismów z Archiwum Radziwiłlowskiego, znajdujacych się w Bibliotece Ordynacyi Krasińskich połaczonej z Muzeum Konstantego Świdzińskiego, Warszawa 1876, s. 3-27. 
celu wybudowanym dworze-muzeum w Chrobrzu. Szybko jednak sposób udostępniania zbiorów (trudność z dotarciem zainteresowanych badaczy do prowincjonalnego Chroberza) oraz sprzeniewierzenie się ostatniej woli benefaktora (Wielopolski nazwał placówkę Biblioteką Ordynacji Myszkowskiej) wywołało oburzenie opinii publicznej oraz szeroką dyskusję na łamach prasy. Ostatecznie spory przerodziły się w sądowe batalie, które ostatecznie doprowadziły do zrzeczenia się przez Wielopolskiego zapisu Konstantego na rzecz jego bratanków - Tytusa i Ludwika Świdzińskich. Ci natomiast zadecydowali w 1860 roku o przekazaniu zbiorów do Biblioteki Ordynacji Krasińskich z zastrzeżeniem utrzymania ich odrębności jako Muzeum Konstantego Świdzińskiego ${ }^{20}$. Przez kolejne dziesięciolecia bibliotekarze BOK porządkowali, opracowywali oraz wydawali drukiem materiały wchodzące w skład przekazanych zbiorów ${ }^{21}$. Jedną z pierwszych opublikowanych edycji opartych na kolekcji Świdzińskiego był tom listów Jana Karola Chodkiewicza przygotowany do druku przez bibliotekarza Biblioteki Ordynacji Krasińskich Władysława Chomętowskiego, poprzedzony wspomnianym omówieniem archiwaliów radziwiłłowskich wchodzących w skład przejętych zbiorów ${ }^{22}$.

W publikacji W. Chomętowski podał regesty (o różnej szczegółowości opisu) 33 listów i mandatów z lat 1521-1597 o niewątpliwie nieświeskiej proweniencji23. Wśród nich znajdujemy wszystkie listy, które wykazał F. Pułaski w swoim katalogu, z wyjątkiem dwóch: listu króla do Barbary Radziwiłłówny z 14 sierpnia 1548 roku oraz do Mikołaja „Rudego” z 16 maja 1571 roku. Trudno jednoznacznie wytłumaczyć owe braki. Możliwe, że listy te trafiły do biblioteki ordynacji z Nieświeża nie przez kolekcję Świdzińskiego, lecz inną, nieustaloną jeszcze drogą. Porządkujący rękopisy w Bibliotece Ordynacji Krasińskich w zbiory (w tym przypadku „Pisma królewskie") i - w ich obrębie - poszczególne tomy (nadano im układ chronologiczny) łączyli materiały o różnym pochodzeniu ${ }^{24}$.

Otwarte pozostaje pytanie, w jaki sposób listy z archiwum Radziwiłłów w Nieświeżu trafiły w ręce Świdzińskiego. Prawdopodobnie stało się to za sprawą działalności Kajetana Kwiatkowskiego, który w latach $1804-1810$ był zatrudniony jako bibliotekarz nieświeski. Korzystając z zajmowanego stanowiska, braku nadzoru oraz nieskrępowanego dostępu do zbiorów radziwiłłowskich, Kwiatkowski wykradał na szeroką, obecnie trudną od oszacowania, skalę rękopisy (zarówno dokumenty

20 K. Ajewski, Kolekcjonerstwo Konstantego Świdzińskiego. Z dziejów Biblioteki Ordynacji Krasińskich, „Rocznik Biblioteki Narodowej” 2004, R. 34, s. 21-78. Tam też obszerna literatura przedmiotu.

${ }^{21}$ H. Tchórzewska-Kabata, Ocalone dla potomnych. Serie wydawnicze Biblioteki Ordynacji Krasińskich. Propozycja badawcza, „Rocznik Biblioteki Narodowej” 2004, 34, s. 79-82.

22 Zob. przyp. 19.

23 W. Chomętowski, op. cit., s. 12-13, poz. 20, 23-27. Regesty potwierdzają poprawną identyfikację miejsc wystawienia listów zaproponowaną przez autorów artykułu recenzyjnego.

${ }_{24}$ J. Wiśniewski, Zbiory archiwalne polskich bibliotek fundacyjnych XIX w., „Poznański Rocznik Archiwalno-Historyczny” 2003/2004, 10/11, s. 105. Praktykę tę potwierdza także informacja F. Pułaskiego że rkps 4001, „podobnie jak trzynaście pozostałych (rpks nr 206-219), (4001-4014) powstał z luźnych papierów, pochodzących już to z zbiorów K. Świdzińskiego, już to z późniejszych darów i nabytków" (K. Pułaski, op. cit., s. 162, przyp.*). 
papierowe, jak i dyplomy pergaminowe) z powierzonego mu zbioru. „Złodziej ksiąg”, jak nazwał go Lelewel ${ }^{25}$, wykorzystywał zrabowane materiały do własnych prac badawczych, jak też do budowania swojej pozycji w środowisku naukowym. Gdy jednak ostatecznie w 1818 roku jego działalność wyszła na jaw, starał się możliwie szybko sprzedać skradzione materiały. Nabywców szukał wśród najbardziej znanych kolekcjonerów epoki - ks. Adama Jerzego Czartoryskiego, Edwarda Raczyńskiego oraz Tytusa Działyńskiego, który ostatecznie „zbiory” Kwiatkowskiego nabył w czerwcu 1821 roku. Śladami szukania chętnego na zakup skradzionych materiałów są przekazywane przez złodzieja „,próbki” - pojedyncze dokumenty znajdujące się w zbiorach Biblioteki Czartoryskich w Krakowie, poznańskiej Biblioteki Raczyńskich oraz Biblioteki Kórnickiej ${ }^{26}$.

Nie dysponujemy bezpośrednimi dowodami potwierdzającymi kontakty Świdzińskiego z byłym nieświeskim bibliotekarzem, lecz są pewne przesłanki pozwalające wskazywać, że również jemu Kwiatkowski zaproponował nabycie skradzionych archiwaliów. Jedną z nich jest fakt, że w zbiorach Muzeum Świdzińskiego znajdujemy listy Zygmunta Augusta z Radziwiłłami, które chronologicznie wiążą się z korespondencją zidentyfikowaną w zbiorach Biblioteki Czartoryskich i Kórnika, tj. z przełomu lat 60. i 70. XVI wieku. Rozstrzygające byłoby zidentyfikowanie na listach z BOK XVIII-wiecznych sygnatur nieświeskich. Zarówno w Kórniku, jak i w Bibliotece Czartoryskich znajdujemy dokumenty pochodzące $\mathrm{z}$ tych samych fascykułów nieświeskich ${ }^{27}$. Niestety ani F. Pułaski, ani W. Chomętowski, regestrując interesujące nas dokumenty, nie podali ich starych sygnatur.

Listy nie znalazły się w żadnej z licznych edycji korespondencji Zygmunta Augusta z Radziwiłłami, nie weszły również (być może ze względu na brak edycji) do szerokiego obiegu naukowego. Kres ich istnieniu, jak zresztą właściwie całych zbiorów Biblioteki Ordynacji Krasińskich, położyła II wojna światowa ${ }^{28}$. Wydawało się, że jedynym świadectwem po tym niewielkim fragmencie korespondencji ostatniego Jagiellona z litewskimi dostojnikami będą krótkie streszczenia podane przez W. Chomętowskiego ${ }^{29}$ i wyliczenie w katalogu F. Puławskiego.

Szczęśliwie treść dwóch listów ze zbiorów Konstantego Świdzińskiego dotrwała do naszych czasów. Pierwszy z nich to list króla do Mikołaja Krzysztofa Radziwiłła

25 Listy emigracyjne Joachima Lelewela, wyd. i wstęp H. Więckowska, t. 4 (1849-1861), Wrocław-Kraków 1954, nr 1203, s. 403; zob. koniekturę przytoczonego fragmentu - B. Krakowski, Kajetan Kwiatkowski, PSB, t. XVI, Wrocław 1971, s. 358.

26 Szerzej na temat działalności K. Kwiatkowskiego zob. R. Jaworski, Z najdawniejszych dokumentów do dziejów domeny Radziwiłłowskiej, „Studia Źródłoznawcze” 2001, t. 39, s. 101-114; idem, Nieznana korespondencja..., s. 92-94.

27 Zob. R. Jaw orski, Nieznana korespondencja..., s. 94, przyp. 22.

${ }_{28}$ W. Kamieniecki, Straty Biblioteki Ordynacji Zamojskich w zakresie zbiorów rękopiśmiennych [w:] Straty archiwów i bibliotek warszawskich zakresie rękopiśmiennych źródet historycznych, t. III: Biblioteki, Warszawa 1955, s. 143-176.

29 Witold Kamieniecki, pisząc o pracy W. Chomętowskiego, stwierdził, że tenże kolekcję rękopisów pochodzącą z Archiwum Radziwiłłów opisał „bardzo niedbale” (op. cit., s. 148). Porównanie regestu listu z marca $1571 \mathrm{r}$. z jego tłumaczeniem autorstwa S. Bodniaka nie potwierdza jednak tego kategorycznego stwierdzenia (zob. list nr 5 niniejszej edycji). 
„Sierotki” z Warszawy z 1 października 1571 roku ${ }^{30}$, którego treść znamy z XVII-wiecznego polskiego thumaczenia ${ }^{31}$. Drugi natomiast to list Zygmunta Augusta do Mikołaja Radziwiłła „Rudego” pisany w Warszawie 24 marca 1571 roku.

Nad listem tym pochylił się Stanisław Bodniak ${ }^{32}$ podczas pracy nad inwentarzami rękopisów Biblioteki Ordynacji Krasińskich. Kórnicki bibliotekarz pracował w warszawskiej bibliotece od lipca 1940 do lipca 1944 roku. Korzystając z możliwości, kontynuował swoje jeszcze przedwojenne badania nad polityką morską ostatnich Jagiellonów. Historyk zdecydował się na skopiowanie rzeczonego listu ze względu na fragment dotyczący obecności korsarzy moskiewskich na Bałtyku w latach 70 . XVI wieku. Interesujący go fragment transkrybował, a resztę listu (po opuszczeniu formuł początkowych i końcowych) podał w przekładzie. Miejsce i datę listu umieścił Bodniak na początku kopii wraz z sygnaturą rękopisu i informacją o języku, w którym list został spisany ${ }^{33}$. Historyk wykorzystał sporządzony odpis w opublikowanej w 1946 roku pracy o polityce morskiej Zygmunta Augusta. Ostatecznie w obszernej pracy przywołał zaledwie fragment jednego zdania $z$ interesującego nas listu ${ }^{34}$.

Głównym tematem listu jest sprawa poselstwa moskiewskiego, które miało przywieźć dokumenty potwierdzające ratyfikację rozejmu zawartego w Moskwie 24 czerwca 1570 roku przez polskich posłów ${ }^{35}$. Początkowo poselstwa spodziewano się w Wielkim Księstwie pod koniec października 1570 roku. Król planował przyjąć je w Grodnie w połowie listopada ${ }^{36}$. Sprawa poselstwa wróciła w lutym następnego roku. W cedule załączonej do listu z 4 lutego 1571 roku król zastanawia się, gdzie obecnie stanęło poselstwo moskiewskie - czy w Smoleńsku, czy już w Orszy. Ostatecznie władca dochodzi do konkluzji, że posłowie nie dotarli jeszcze nawet do Smoleńska ${ }^{37}$. Niepokój wzbudzały również pogłoski (jak się okazało nieprawdziwe), jakoby w Moskwie zmarli car Iwan IV Groźny oraz jego syn i następca, carewicz

30 W. Chomęt ow ski, op. cit., s. 13, poz. 27 (z błędną datą dzienną: 8 października).

31 Warszawa, Archiwum Główne Akt Dawnych, Archiwum Radziwiłłów, oddz. II, sygn. 70, s. 3-4. (ed. Listy, s. 604-605, nr 359). Porównanie regestu Chomętowskiego z zachowaną kopią potwierdza domysł, że w Bibliotece Ordynacji Krasińskich przechowywany był oryginał tegoż listu (zob. M. Janicki, R. Jaworski, op. cit., s. 364, przyp. 66).

32 S. Bodniak, Życiorys własny, „Pamiętnik Biblioteki Kórnickiej” 1955, z. 5, s. 16-17.

33 Zob. w edycji uwagi do dok. nr 5.

34 S. Bodniak, Polska a Battyk za ostatniego Jagiellona, „Pamiętnik Biblioteki Kórnickiej” 19391946, z. 3, s. 173, przyp. 3.

35 Na temat poselstwa oraz okoliczności towarzyszących zawieraniu rozejmu zob. H. Grala, Dyplomacja $z$ upominkami $w$ tle (Wokót ceremonialu dyplomatycznego $w$ stosunkach polsko-moskiewskich XVI-XVII w.) [w:] Skarby Kremla. Dary Rzeczpospolitej Obojga Narodów. Wystawa ze zbiorów Państwowego Muzeum Historyczno-Kulturalnego „Moskiewski Kreml”, Warszawa 1998, s. 47-53; idem, Upadek , moskiewskiego kanclerza”. Iwan Wiskowaty i Iwan IV w 1570 r., „Kwartalnik Historyczny" 1994, R. 101, z. 1, s. 60-63. Posłowie wrócili z Moskwy w drugiej połowie sierpnia 1570 r. (zob. list króla do Pawła Paca, kasztelana witebskiego, Warszawa, 25 VIII 1570 r.; regest: W. Chomętowski, op. cit., s. 12, nr 22).

36 Listy, s. 581-585, nr 345 (Warszawa, 24 X 1570).

37 Listy, s. 590, nr 348 (Warszawa, 4 II 1571). 
Iwan $^{38}$. W liście do Mikołaja Radziwiłła „Rudego” z 4 marca 1571 roku król pisze, że informacje o nadciąganiu poselstwa moskiewskiego, ,kto posłom idzie i jako wielki poczet z nimi jest [...], a na granicach kiedy będą”, które przesłał „Rudy”, potwierdzili swoimi listami Mikołaj Naruszewicz, podskarbi nadworny litewski, oraz Filon Kmita Czarnobylski, starosta oszmiański. Zygmunt August zgodził się, by Radziwiłł stanął w Borysowie i zbierał informacje na temat poselstwa. Szczególnie wiele uwagi zaprzątała sprawa, kto posłów wysłał, dlatego też liczył, że Radziwiłłowi uda się w Borysowie ustalić losy cara Iwana i jego syna ${ }^{39}$.

W liście poruszone zostały jeszcze dwie kwestie dotyczące relacji państwa Jagiellonów z Moskwą. Pierwsza z nich to problem pojawienia się na Bałtyku moskiewskich frajbiterów (kaprów). Moskiewska flota kaperska została powołana przez wielkiego księcia moskiewskiego w maju 1570 roku we współpracy z sojuszniczą Danią. Owocem tej współpracy było utworzenie w czerwcu operującej z Bornholmu, liczącej 15 jednostek flotylli dowodzonej przez admirała Kerstena-Rodego. Jej działania trwały zaledwie kilka miesięcy (do listopada 1570 r.) i koncentrowały się na paraliżowaniu polskich i szwedzkich szlaków komunikacyjnych. Poczynania kaprów moskiewskich spotkały się z militarną reakcją polską i szwedzką, która ostatecznie doprowadziła do rozbicia moskiewskich kaprów. Ostatecznie flotylla została zlikwidowana po kongresie w Szczecinie, kiedy Dania wycofała się ze wspierania swego dotychczasowego sojusznika.

W liście król również ustosunkowuje się do zapytania wojewody o prośby kupców moskiewskich proszących o zgodę na podróż z towarami szlakiem wodnym z Połocka do Wilna rzeką Dzisną. Monarcha odmówił, obawiając się, że puszczenie kupców moskiewskich nowym szlakiem w rzeczywistości ma służyć wytyczeniu szlaku wodnego Dźwiną do Rygi, co godziło w interesy gospodarcze Wilna i Wielkiego Księstwa Litewskiego. Dodatkowo król poruszył sprawę wzajemności w kontaktach handlowych z Moskwą - jeśli kupcy z państwa Jagiellonów będą mogli swobodnie prowadzić handel na wschodzie, to kupcy moskiewscy będą mogli liczyć na wzajemność.

Na marginesie niniejszej edycji listów ruskich (co prawda zachowanych jedynie w formie polskich streszczeń i przekładu jednego z nich) warto poruszyć kwestię miejsca listów pisanych cyrylicą w korespondencji wymienianej pomiędzy Zygmuntem Augustem i Radziwiłłami. Henryk Lulewicz w swoim przywoływanym wyżej artykule recenzyjnym podkreślił ich niewątpliwie „oficjalny” i „bardziej sformalizowany charakter" niż w przypadku listów w języku polskim. Spisane w języku ruskim, czyli języku urzędowym Wielkiego Księstwa, uwierzytelnione litewską pieczęcią kanclerską lub podkanclerską, opatrzone dodatkowo podpisem jednego z pisarzy litewskich (dodajmy: często również sygnowane przez samego króla), były „przesyłane przez kancelarię litewską do poszczególnych dostojników, względnie adresowane zbiorowo do większej liczby panów-rad, w sprawach dotyczących żywotnych

${ }^{38}$ Listy, s. 591, nr 350 (Warszawa, 28 II 1571). Na temat zamieszania na dworze królewskim wywołanym wieściami o śmierci Iwana i jego syna zob. M. Ferenc, Mikołaj Radziwilt „Rudy” (ok. 1515-1584). Działalność polityczna i wojskowa, Kraków 2008, s. 374-376.

39 Listy, s. 592, nr 351 (Warszawa, 4 III 1571). 
interesów państwa". Historyk kwestionuje więc sens wspólnej publikacji listów polskich i ruskich. Dodatkowym argumentem przeciwko wydawaniu korespondencji ruskiej jest jej ogromna liczba oraz rozproszenie ${ }^{40}$.

Nie kwestionując spostrzeżeń o generalnej różnicy pomiędzy charakterem korespondencji ruskiej i polskiej, trudno zgodzić się z ostatecznym wnioskiem. Przez rezygnację z uwzględnienia $\mathrm{w}$ nowej edycji części korespondencji a priori - na podstawie kryterium językowego - i przyjęcie założenia, że listy polskie to korespondencja ,prywatna”, a korespondencja ruska ma charakter ściśle „urzędowy” umyka wielopłaszczyznowość tego pisemnego dialogu prowadzonego pomiędzy królem a jego radziwiłłowskimi adherentami. Korespondencja ta nawzajem się przenikała, a tematy poruszone w listach kierowanych do ogółu panów-rad, w „naukach” przesyłanych indywidualnie do poszczególnych Radziwiłłów, oraz listy o charakterze poufnym pisane w większości przypadków po polsku, nawzajem się uzupełniają. Często znajdujemy w listach polskich odniesienia do korespondencji „urzędowej”. Widać to doskonale choćby na przykładzie omawianej tu korespondencji z 1571 roku. Listy polskie są swoistym komentarzem do pism oficjalnych król wyjaśnia w nich intencje swoich decyzji. Inną niezmiernie ważną kwestią jest wzajemne uzupełnianie się korespondencji. Listy polskie, zachowane $\mathrm{w}$ liczbie około 400, to zaledwie ułamek korespondencji, jaką Radziwiłłowie wymieniali ze swym monarchą i powinowatym jednocześnie. Braków w tej korespondencji nie łagodzą również listy pisane przez Radziwiłłów do króla. Przyszła edycja nie może się ograniczać jedynie do wydania listów kierowanych do króla i musi uwzględniać te nieliczne zachowane (najczęściej w kopiach) listy pisane do monarchy. Istotą korespondencji jest dialog, a nie monolog. Dzięki temu może łatwiej byłoby wyjaśnić niezrozumiałe dla nas dotychczas wątki pojawiające w listach królewskich.

O ile można się zgodzić co do zasady, by w przyszłej edycji listy, w których członek rodu Radziwiłłów jest wymieniany wśród innych panów-rady lub które mają charakter czysto formalny, oddawać jedynie w formie regestów, to głębszego zastanowienia wymaga kwestia listów określanych przez źródła mianem nauk hospodarskich. Rzeczywiście duża część z nich to rozstrzygnięcia o charakterze prawnym lub polecenia (mandaty) władcy kierowane do kolejnych Radziwiłłów jako wojewodów bądź hetmanów wielkich litewskich, lecz i w nich pojawiają się informacje wykraczające poza korespondencję między królem a członkiem rady hospodarskiej. Świadczyć mogą o tym zanotowane niejako na marginesie meritum uwagi czy dygresje królewskie, świadczące o specyfice relacji pomiędzy Jagiellonem a Radziwiłłami, wykraczające poza formularz tego typu dokumentów ${ }^{41}$. Na refleksję naukową czeka zarówno ars epistolandi Zygmunta Augusta (na tle epoki i tradycji epistolarnej Jagiellonów), jak i uchwycenie osobistego udziału króla w powstawaniu listów (od autografów przez królewski dyktat po jedynie akceptację tekstu potwierdzoną

40 H. Lulewicz, Daremny trud edytora?, s. 184-185.

41 Dobrym przykładem jest żart, na który pozwolił sobie król w liście (mandacie) ruskim do Mikołaja Radziwiłła Rudego (Piotrków, 18 VI 1550). Monarcha, podejmując decyzję w sprawie uwięzienia za długi szlachcica Mikołaja Wrony, pisze: „Proto pan tot Vrona niechaj c turmy ne wyljataet', aliž to vse, što na nem' prisužono každomu zaplatit”' (R. Jaw orski, Nieznana korespondencja..., s. 99, nr 3). 
królewskim podpisem i/lub pieczęcią). Wskazane wyżej pola badawcze winny być poprzedzone jednak podjęciem badań nad typologią monarszej epistolografii (być może w ujęciu systemowym) oraz jej miejsca w całokształcie produkcji obu kancelarii - koronnej i litewskiej ${ }^{42}$.

Losy listów będących przedmiotem niniejszego tekstu pokazują, że nawet w przypadku rękopisów, które jak się wydaje, bezpowrotnie i nieodwołalnie straciliśmy, zawsze istnieje szansa, że przetrwały, co prawda jedynie w formie kopii, dzięki pracy naszych poprzedników ${ }^{43}$.

\section{ZASADY EDYCJI}

Opracowanie edytorskie opiera się na zaleceniach instrukcji wydawniczej dla nowożytnych źródeł historycznych, przygotowanej przez Komisję Historyczną Polskiej Akademii Umiejętności w 1949 roku $^{44}$.

\section{Zygmunt August do Mikołaja Radziwiłła [Rudego], Warszawa, 20 października 1568 roku}

Oryg.: Warszawa, Biblioteka Ordynacji Krasińskich, rkps 4001 (zniszczony w 1944 r.). Reg. 1: F. Pułaski, Opis 815 rękopisów Biblioteki Ordynacji Krasińskich, Warszawa 1915, s. 169. Reg. 2: W. Chomętowski, Rękopisma z Archiwum Radziwillowskiego znajdujace się w Bibliotece Hrabiów Krasińskich z Muzeum Konstantego Świdzińskiego [w:] Korespondencye Jana Karola Chodkiewicza: poprzedzone opisem rękopismów z Archiwum Radziwillowskiego, znajdujących się w Bibliotece Ordynacyi Krasińskich połaczonej z Muzeum Konstantego Świdzińskiego, Warszawa 1876, s. 11, poz. 20. Edycja za Reg. 2.

42 W. Chorążyczewski, Czego wciąz nie wiemy o kancelariach centralnych dawnej Rzeczypospolitej [w:] Belliculum diplomaticum IV Thorunense. Dyplomatyka staropolska - stan obecny i perspektywy badań, red. W. Chorąży czewski, J. Tandecki, Toruń 2011, s. 47-74.

${ }_{43}$ Szczególnie jeśli weźmiemy pod uwagę metodykę pracy naukowej historyków z XIX i pierwszej połowy XX w., która opierała się na sporządzaniu odpisów niezbędnych źródeł. Warto również zwrócić uwagę na to, jak wielu historyków interesujących się dziejami państwa Jagiellonów w XVI w. pracowało w zbiorach petersburskich i zostawiło po sobie często dość pobieżnie jeszcze rozpoznane spuścizny (zob. H. Grala, Polscy historycy i archiwiści w carskim Petersburgu (tekst wystąpienia wygłoszonego podczas Międzynarodowej Konferencji „Polski Petersburg - historia i pamięć”, zorganizowanej w Sankt Petersburgu w dniach 10-14 kwietnia 2013 r. przez Rosyjskie Państwowe Archiwum Historyczne i Międzynarodowe Centrum Kultury w Krakowie); http://www.polskaipetersburg.pl/images/upload/biblioteka/Polscy_ historycy_i_archiwisci_w_carskim_Petersburgu_Hieronim_Grala.pdf (dostęp: 18.06.2017).

44 Instrukcja wydawnicza dla źródel historycznych od XVI do polowy XIX wieku, red. K. Le pszy, Wrocław 1953. 
Zygmunt August do Mikołaja Radziwiłła ${ }^{45}$, wojewody wileńskiego, kanclerza Wielkiego W. Księstwa Litewskiego, o unii Litwy z Koroną Polską i o przyjeździe na sejm do Lublina. Dan z Warszawy d. 20 października 1568 r. Z pieczęcią.

\section{Zygmunt August do Mikołaja Radziwiłła [Rudego], Warszawa, 15 września 1570 roku}

\section{Oryg.: Warszawa, Biblioteka Ordynacji Krasińskich, rkps 4001 (zniszczony} w 1944 r.). Reg. 1: F. Pułaski, Opis, s. 169. Tu z błędną datą roczną: 1571. Reg. 2: W. Chomętowski, Rękopisma, s. 12, poz. 24.

Zygmunt August do tegoż. Donosi o liście papieża ${ }^{46} \mathrm{z}$ upomnieniem o zwrócenie Prus mistrzowi niemieckiego zakonu ${ }^{47}$, dalej, że Magnus ${ }^{48}$, książę holsztyński, zawarł przymierze $\mathrm{z}$ wielkim księciem moskiewskim ${ }^{49}$, zebrał niemałe wojsko i obległ Rewel zamek ${ }^{50}$ króla szwedzkiego $^{51}$, na koniec, że rozesłał listy, w których tytułuje się królem inflantskim ${ }^{52}$. Dan w Warszawie 15 września 1570 r. Pieczęć odpadła.

45 Mikołaj Radziwiłł zw. Rudym h. Trąby (1512-1584), podczaszy wlk. litewski (1544-1551), łowczy wlk. litewski (1546-1554), sprawca (1549-1550), a następnie wojewoda trocki (1550-1566), hetman najwyższy litewski $(1553,1556-1566,1577,1578-1584)$, wojewoda wileński (od 1566), kanclerz wlk. litewski (1566-1579), hetman inflancki (od 1578) (Urzędnicy centralni i dostojnicy Wielkiego Księstwa Litewskiego XIV-XVIIII w. Spisy, oprac. H. Lulewicz, A. Rachuba, Kórnik 1994 (dalej: Urz. WKL), s. 234; H. Lulewicz, Radziwitt Mikołaj zwany Rudym, PSB, t. XXX, Wrocław 1987, s. 321-325; M. Ferenc, Mikołaj Radziwitt „,Rudy”..., passim).

46 Pius V (wł. Michele Ghislieri; 1504-1572), papież od $1566 \mathrm{r}$.

47 Georg Hundt von Weckheim (1520-1572), administrator urzędu wielkiego mistrza zakonu krzyżackiego (1566-1572), do zakonu krzyżackiego wstąpił w 1544 r. Komtur Weissenburga (od 1553), komtur we Frankfurcie (od 1558), a następnie krótko komtur krajowy baliwatu frankońskiego. Jako zwierzchnik zakonu związał zakon z Habsburgami, wielokrotnie wykonywał różne zlecenia dyplomatyczne Maksymiliana II. Po śmierci Albrechta Habsburga z poparciem dworu cesarskiego i Watykanu podjął bezskuteczne starania o odzyskanie Prus. Pierwszy list z poparciem dla pretensji zakonu do Prus papież Pius V skierował do Zygmunta Augusta w czerwcu 1570 r. (ed. Vetera monumenta Poloniae et Lithuaniae gentiumque finitimarum historiam illustrantia; maximam partem nondum edita ex tabulariis Vaticanis deprompta collecta ac serie chronologica disposita T.2 ab Ioanne PP. XXIII. usque ad Pium PP. V. 1410-1572, Romae 1861, s. 747, nr 794; zob. S. Bodniak, Najdawniejszy plan porozumienia Polski z Moskwa przeciw Niemcom z lat 1571-72, „Pamiętnik Biblioteki Kórnickiej” 1947, z. 4, s. 82).

48 Magnus Inflancki (1540-1583), syn Chrystiana III, króla Danii, książę Holsztynu, król Inflant (1570-1577), książę-biskup Ozylii (1560-1572), książę-biskup Kurlandii (1560-1583). Zob. W.B. Stasiew ski, Magnus [w:] Neue Deutsche Biographie, Bd. 15, Berlin 1987, s. 865-866.

$49 \mathrm{Tj}$. Iwanem IV Groźnym. O przymierzu Magnusa z wielkim księciem moskiewskim zob. A. Adamson, Magnus in Moscow, „Acta Historica Tallinnensia” 2011, vol. 16, s. 67-85.

50 Magnus posiłkowany przez Moskwę oblegał bez powodzenia opanowany przez Szwedów Rewal (dziś Tallin) od końca sierpnia 1569 r. do marca 1571 r. Zob. M. Plewczyński, Wojny i wojskowość polska w XVI wieku, t. 2: Lata 1548-1575, Warszawa 2012, s. 257-258; I.B. B abulin, Osada Revelja (1570-1571 gg.) po danym hroniki Bal'tazara Rjussova [w:] Istorja voennogo dela: issledovanja i istočniki, t. 6, Moskva 2016, s. 326-391.

51 Jan III (1537-1593), książę Finlandii (1556-1563), król Szwecji (1569-1593).

52 Magnus zaczął używać tytułu króla Inflant w lipcu 1570 r. Zob. A. Adamson, Prelude to the Birth of the “Kingdom of Livonia”, „Acta Historica Tallinnensia” 2009, vol.14, s. 31-61. 


\section{Zygmunt August do Mikołaja Radziwiłła [Rudego], Warszawa, 15 marca 1571 roku}

Oryg.: Warszawa, Biblioteka Ordynacji Krasińskich, rkps 4001 (zniszczony w 1944 r.). Reg. 1: F. Pułaski, Opis, s. 169. Reg. 2: W. Chomętowski, Rękopisma, s. 12, poz. 23. Edycja za Reg. 2.

Zygmunt August do Mikołaja Radziwiłła ${ }^{53}$. Donosi, że otrzymał wiadomość od Jerzego Chodkiewicza ${ }^{54}$, kasztelana wileńskiego, hetmana wielkiego W. Księstwa Litewskiego, jako wojewoda połocki W. Ks. Moskiewskiego Andrzej Iwanowicz Suzdalski ${ }^{55}$ przysłał gońca swego do niego i do Radziwiłła z listem, w którym uskarża się na krzywdy wyrządzone po zawarciu przymierza poddanym moskiewskim przez starostów i poddanych królewskich. Zaleca zatem król Radziwiłłowi, ażeby roztrząsnął tę sprawę w porozumieniu z Jerzym Chodkiewiczem i odprawił moskiewskiego gońca. Dan w Warszawie 15 marca 1571 r. Podpisał Mikołaj Bonar ${ }^{56}$. Pieczęć odpadła.

\section{Zygmunt August do Mikołaja Radziwiłła [Rudego], Warszawa, 24 marca 1571 roku}

Oryg.: Warszawa, Biblioteka Ordynacji Krasińskich, rkps 4001, k. 78 (zniszczony w 1944 r.). Kop.: Biblioteka Kórnicka, rkps 11591/2 (w formie ttumaczenia z fragmentem transkrybowanym) na podst. Oryg. Reg. 1: F. Pułaski, Opis, s. 169. Reg. 2: W. Chomętowski, Rękopisma, s. 12-13, poz. 25. Uwaga: Ze względu na wzajemne uzupetnianie się informacji z Reg. 2 i Kop. zdecydowano się na publikacje obu przekazów. W przypadku Kop. fragment transkrybowany oddano czcionka rozstrzelona.

53 Zob. przyp. 44.

54 Hrehory Aleksandrowicz Chodkiewicz h. Kościesza (zm. 1572/1573), podkomorzy wlk. lit. (1544-1559), wojewoda wileński (1554), kijowski (1555), kasztelan wileński (od 1564), kasztelan trocki (od 1559), hetman dworny (1561-1566), hetman najwyższy (od 1566). Zob. Urzędnicy WKL, s. 203; J. Jasnowski, Chodkiewicz Grzegorz, PSB, t. 3, Kraków 1937, s. 358-359.

55 Kn. Andrzej Iwanowicz Nogtiew-Suzdalski (zm. 1579), rosyjski dowódca, wojewoda Wielkich Łuk (1564), Połocka (1565-1574), Muromia (1574-1576) oraz Kazania (od 1576). Zob. Enciklopedičeskij slovar, t. 21, izd. F.A. Brokgauz, I.A. Efron, S. Peterburg 1897, s. 314.

56 Niezidentyfikowany. W tym czasie wśród pisarzy hospodarskich nie znajdujemy nikogo nawet o zbliżonym brzmieniowo nazwisku. Najprawdopodobniej Chomętowski błędnie odczytał nazwisko pisarza. 


\section{Kop.:}

Posłowie cara ${ }^{57}$ do nas idą i już są w państwie naszym ${ }^{58}$. Nie mam Panów rad przy sobie i rozkazałem posłów zatrzymać w Brześciu ${ }^{59}$ i dla odprawy ich rad bym tam gdzie bliżej jechać do naszego państwa litewskiego, ale zdrowie nasze nie doborowe i w drodze mogłoby się pogorszyć, a też droga zła. Dlatego nie mogąc tam jechać przyjmę i odprawię tych posłów w Warszawie. Kazałem im wyjechać do Warszawy po Wielkanocy [= po $15 \mathrm{IV}$ ], chcąc ich przyjąć najdalej na drugą niedzielę po Wielkanocy [= $29 \mathrm{IV}]$. Chciałbym, żebyś w tym czasie był tu, jeśli możesz, jako kanclerz i świadom tych spraw naszych z tym nieprzyjacielem ${ }^{60}$. Chciałbym byś w oznaczonym czasie był tu, tak dla przyjmowania posłów jak i dla namów mnogich potrzeb ziemskich. Gdybyś z jakich przyczyn nie mógł, uważając dla to potrzeby i przypadki których wżo jako z ustanowienia pokoju z tym nieprzyjacielem tak i z nowin szto nas z Rzeszy doszły (a co Wasci dostatecznie wypisane ${ }^{61}$. Estly szto z timy posły wzczynaty maiemo rozkazaty, zwłaszcza iż też nam w tych czasach doszedł list przez tego niepryjate$1 a^{62}$ danyj frajbyterom ${ }^{63}$ eho na morze, kotoroho kopeju Twojej Miłosty poszyłajemo. Obaczysz Twoja Miłost recz niezwykłuju i niebywałuju za prodkow jeho. Jestli o tom z posły mowyty abo czerez naszoho posłanca otprawyty ku nema ${ }^{64}$, o wsem tom z łaski swoje nam wypisał by.

57 Mowa o poselstwie moskiewskim wysłanym przez cara Iwana IV Groźnego. W jego skład wchodzili kn. Grigorij Meszczerski, kn. Grigorij Putjatin i diak Piotr Protaszew. Zob. N.N. Bantyš-Kamenskij, Obzor vniešnich snošenij Rossii (po 1800 g.), č. 3, Moskva 1897, s. 101; „Vypiska iz posolskich knig” o snošenijach Rossijskogo gosudarstva s Polsko-Litovskim za 1547-1572 gg., [= Pamjatniki istorii Vostočnoj Evropy. Istočniki XV-XVII v.t. 2], Moskva-Varšava 1997, s. 2.

58 Listy, s. 592, nr 351 (Warszawa, 4 III 1571).

59 Brześć Litewski (Brześć nad Bugiem; białorus. Brest) - miasto u ujścia Muchawca do Bugu, stolica woj. brzeskolitewskiego.

60 Poselstwo przybyło, by odebrać zaprzysiężenie trzyletniego rozejmu (do czerwca $1573 \mathrm{r}$.) zawartego 29 VI 1570 r. przez poselstwo Rzeczypospolitej, na którego czele stali Jan Krotoski, wojewoda inowrocławski, i Mikołaj Talwosz, kasztelan miński. Zygmunt August zaprzysiągł rozejm i wystawił odpowiedni dokument 8 V 1571 r. Zob. N.N. Bantyš-Kamenskij, op. cit.; R. Żelew ski, Dyplomacja polska w latach 1506-1572 [w:] Historia dyplomacji polskiej, t. 1: Polowa X-1572, red. M. Biskup, Warszawa 1980, s. 703-704; J. Natanson Leski, Dzieje granicy wschodniej Rzeczypospolitej, cz. I: Granica moskiewska w epoce jagiellońskiej, „Rozprawy Historyczne Towarzystwa Naukowego Warszawskiego", t. 1, z. 3, Lwów-Warszawa 1922, s. 176-183.

${ }_{61}$ Listy, s. 594-595, nr 353 (Warszawa, 11 IV 1570).

62 Iwana IV Groźnego.

${ }^{63}$ Fraibiterzy - inaczej: kaprzy. Zob. S. Bodniak, Polska a Bałtyk..., s. 164-165; R. Gaziński, Die Kaperflotte von Iwan IV. dem Schrecklichen im Lichte von Akten des Herzoglich Stettiner Archiv, „Studia Maritima” 2013, R. 26, s. 29-37.

${ }^{64} \mathrm{Z}$ późniejszej korespondencji króla z Radziwiłłem Rudym wiemy, że posłowie nie chcieli podejmować żadnych rokowań. Ostatecznie król zdecydował wysłać do Moskwy w czerwcu $1571 \mathrm{r}$. poselstwo litewskie na czele z Michałem Haraburdą. Zob. N.N. B an ty š-Ka men skij, op. cit.; Vypiska..., s. 267; R. Żelew ski, op. cit., s. 709-710, przyp. 52; R. Jaw orski, Nieznana korespondencja ..., s. 105, nr 8 (list Zygmunta Augusta do Mikołaja Rudego z Warszawy, 20 V 1571). 
Oznajmił nam starosta dysneński Borkułap Korsak ${ }^{65}$ że możni kupcy moskiewscy, którzy już są u Połocka ${ }^{66}$ domawiają się by ich puścić z Połocka do Dzisny ${ }^{67}$, a z Dzisny do Kazian ${ }^{68}$, a stąd ziemią do Wilna z towarami. Czego nam czynić - dalej do Dzisny wodą nie widzi się puścić, bo potem do Rygi chcieliby jechać wodą. Jeśli naszym kupcom będzie wolno jeździć z towarem do Moskwy, to ja nie będę zabraniał jeździć do państwa naszego z kupiami, ale nie dalej wodą tylko do Dzisny z Połocka, a z Połocka ziemią do Wilna. Borkułabowi napisz żeby on do Połocka kupcom dał znać około tych kupców, nie inaczej jeśli i nasi kupcy z kupiami puszczani będą do ziemi tego nieprzyjaciela naszego, to wtedy i moskiewscy mogą w państwie naszym $^{69}$. Jakie Twe zdanie - - -

\section{Reg. 2:}

Zygmunt August do tegoż. Oznajmuje, iż dowiedziawszy się jako posłowie moskiewscy przyjechali do Litwy, rozkazał zatrzymać się w Brześciu, z przyczyny, że nie ma przy sobie kanclerza Wielkiego Księstwa Litewskiego i panów radnych. Donosi że z powodu słabego zdrowia i złych dróg, pomimo chęci nie może obecnie udać się sam do Litwy. Więc rozkazał posłom przyjechać do Warszawy, zatem wzywa panów radnych do swego boku, szczególnie zaś M. Radziwiłła jako kanclerza. W razie gdyby nie mógł przyjechać w terminie, uprasza Król, aby jako świadomy dobrze całego biegu spraw z pomienionym nieprzyjacielem przysłał mu dokładnie wyłuszczone na piśmie zdanie o sposobie rokowania z posłami. Zwraca tu uwage kanclerza na okoliczności świeżo przejętego listu, który wydał wielki książę moskiewski swym frejbiterom na morzu. Załącza zatem kopią, z uwagą, że jest niezwykłej i niepraktykowanej dotąd treści i zapytuje, czy ma o tem rozmawiać z posłami, czy też umyślnego wysłać w tym przedmiocie posła do wielkiego księcia. Donosi w końcu o przedstawionem żądaniu kupców moskiewskich dozwolenia przejazdu z Połocka do Wilna, uważa za rzecz słuszną zadość uczynić tej prośbie, atoli żąda od Radziwiłła, aby i w tej mierze oznajmił swe zdanie. Dan w Warszawie 24 marca 1571 r. Z pieczęcią. Podpisał Michał Haraburda pisarz litewski ${ }^{70}$.

${ }_{65}$ Borkołab Głębocki Korsak h. własnego (zm. 1576), podstarości mohylewski (1555-1561), rotmistrz królewski (1562-1563), starosta dziśnieński (od 1566). Zob. T. Wa sile w ski, Korsak Borkołab Glębocki, PSB, t. XIV, Wrocław 1968-1969, s. 103-104.

66 Połock - miasto przy ujściu Połoty do Dźwiny. Ważna twierdza na granicy litewsko-moskiewskiej, wielokrotnie oblegana przez wojska moskiewskie, w styczniu 1563 r. zdobyta przez Iwana IV Groźnego.

67 Dzisna (białorus. Dzisna) - miasto na lewym brzegu rz. Dźwiny u ujścia rz. Dzisny, w d. województwie połockim, ok. $40 \mathrm{~km}$ na płn. zach. od Połocka. Po utracie Połocka w 1563 r. Zygmunt August nakazał wzniesienie tu nowego zamku.

${ }^{68}$ Kaziany (białorus. Kazjany) - wieś nad ujściem rzeki Dryświaty do rz. Dzisny, w d. województwie połockim, ok. $90 \mathrm{~km}$ od m. Dzisny.

${ }_{69}$ Strona moskiewska do sprawy otwarcia szlaku wodnego wracała jeszcze później (zob. Listy, s. 355-356, nr 354 (Warszawa, 26 V 1571). A. Waw rzyńc zy k, Studia z dziejów handlu Polski z Wielkim Księstwem Litewskim i Rosja w XVI wieku, Warszawa 1956, s. 28-27.

70 Michał Haraburda h. Abdank (zm. 1586), diak hospodarski, pisarz wlk. lit. (1566-1586), kasztelan miński (od 1584), z polecenia Zygmunta Augusta i Stefana Batorego wielokrotnie posłował na Krym i do Moskwy. Zob. Urzędnicy WKL, s. 209; K. Lepszy, Haraburda Michat, PSB, t. IX, Warszawa 1960-1961, s. 288-290. 


\section{Zygmunt August do Mikołaja Radziwiłła [Rudego], Warszawa, 5 września 1571 roku}

Oryg.: Warszawa, Biblioteka Ordynacji Krasińskich, rkps 4001 (zniszczony w 1944 r.). Reg. 1: F. Pułaski, Opis, s. 169. Reg. 2: W. Chomętowski, Rękopisma, s. 13, poz. 26. Edycja za Reg. 2.

Zygmunt August do księcia Mikołaja Radziwiłła ${ }^{71}$ wojewody wileńskiego, kanclerza W. Księstwa Litewskiego. Zaleca, aby z massy pozostałego majątku po zmarłym w Wilnie Greku Apostole ${ }^{72}$ zapłacono kupcowi tureckiemu Machmetowi Czelebiejowi ${ }^{73} 2,455$ talarów, które zmarły winien był uiścić do skarbu sułtana ${ }^{74}$. Ściągnięcie atoli pomienionego długu ma nastąpić bez pokrzywdzenia innych wierzycieli, poddanych królewskich. Dan w Warszawie 5 września 1571. Z pieczęcią. Podpis Macieja Sawickiego ${ }^{75}$.

\section{BIBLIOGRAFIA}

Adamson A., Magnus in Moscow, „Acta Historica Tallinnensia” 2011, vol. 16, s. 67-85. Adams on A., Prelude to the Birth of the "Kingdom of Livonia”, „Acta Historica Tallinnensia" 2009, vol. 14, s. 31-61.

Ajewski K., Kolekcjonerstwo Konstantego Świdzińskiego. Z dziejów Biblioteki Ordynacji Krasińskich, „Rocznik Biblioteki Narodowej” 2004, R. 34, s. 21-78.

Babulin I.B., Osada Revelja (1570-1571 gg.) po danym hroniki Baltazara Rjussova [w:] Istorja voennogo dela: issledovanja i istočniki, t. 6, Moskva 2016, s. 326-391.

Baliński M., Dopetnienie pamiętników o królowej Barbarze [w:] M. Baliński, Pisma historyczne, Wilno 1856.

Baliński M., Pamiętniki o królowej Barbarze żonie Zygmunta Augusta [w:] M. Baliński, Pisma historyczne, t. 1-2, Wilno 1843.

71 Zob. przyp. 45.

72 Niezidentyfikowany.

73 Mechmet Czelebi, kupiec Wysokiej Porty, członek elitarnej przybocznej honorowej gwardii müteferrika (od 1570), działał na szeroką skalę, handlując towarami na terenie Korony, Litwy i Wielkiego Ks. Moskiewskiego (zob. A. Dziubiński, Na szlakach Orientu. Handel między Polska a Imperium Osmańskim w XVI-XVIII wieku, Wrocław 1997, s. 53-54, 91-93, 186, 198; idem, Stosunki dyplomatyczne polsko-tureckie w latach 1500-1572 w kontekście międzynarodowym, Warszawa 2007, s. 267; Katalog dokumentów tureckich. Dokumenty do dziejów Polski i krajów ościennych w latach 1455-1672, oprac. Z. Abramowicz, red. A. Zajączkowski [= Katalog rękopisów orientalnych w zbiorach polskich, red. S. Strelcyn, współudz. M. Lewicki, A. Zajączkowski, t. 1, cz. 1], Warszawa 1959, passim).

74 Selim II Pijak (1524-1574), sułtan turecki od $1566 \mathrm{r}$.

75 Maciej (Matwiej, Matys) Sawicki h. Lubicz (zm. 1581), pisarz wojewody wileńskiego Mikołaja Radziwiłła Czarnego, wojski mielnicki, podkomorzy drohicki (przed 1566), starosta mielnicki (1569), sekretarz królewski, pisarz litewski (1566-1581), kasztelan podlaski (1574). Zob. Urzędnicy WKL, s. 239; I. Kanie w ska, Sawicki Maciej, PSB, t. XXXV, Kraków 1994, s. 334-336. 
Bantyš-Kamenskij N.N., Obzor vniešnich snošenij Rossii, č. 3, Moskva 1897.

Bodniak S., Najdawniejszy plan porozumienia Polski z Moskwa przeciw Niemcom z lat 1571-72, „Pamiętnik Biblioteki Kórnickiej” 1947, z. 4, s. 78-92.

Bodniak S., Polska a Bałtyk za ostatniego Jagiellona, „Pamiętnik Biblioteki Kórnickiej” 1939-1946, z. 3, s. 42-276.

Bodniak S., Życiorys własny, „Pamiętnik Biblioteki Kórnickiej” 1955, z. 5, s. 7-34.

Chomętowski W., Rękopisma z Archiwum Radziwiłtowskiego znajdujące się w Bibliotece Hrabiów Krasińskich z Muzeum Konstantego Świdzińskiego [w:] Korespondencye Jana Karola Chodkiewicza: poprzedzone opisem rękopismów z Archiwum Radziwiłlowskiego, znajdujących się w Bibliotece Ordynacyi Krasińskich połaczonej z Muzeum Konstantego Świdzińskiego, Warszawa 1876, s. 7-27.

Chorążyczewski W., Czego wciąż nie wiemy o kancelariach centralnych dawnej Rzeczypospolitej [w:] Belliculum diplomaticum IV Thorunense. Dyplomatyka staropolskastan obecny i perspektywy badań, red. W. Chorążyczewski, J. Tandecki, Toruń 2011, s. $47-74$.

Dziubiński A., Na szlakach Orientu. Handel między Polska a Imperium Osmańskim w XVI-XVIII wieku, Wrocław 1997.

Dziubiński A., Stosunki dyplomatyczne polsko-tureckie w latach 1500-1572 w kontekście międzynarodowym, Warszawa 2007.

Enciklopedičeskij slovar, t. 21, izd. F.A. Brokgauz, I.A. Efron, St. Peterburg 1897.

Ferenc M., Listy polskie króla Zygmunta Augusta do Mikołaja Radziwitła „Rudego” z lat 1548-1556, „Prace Historyczne” 2009, z. 136, s. 141-153.

Ferenc M., Mikołaj Radziwitt „Rudy” (ok. 1515-1584). Działalność polityczna i wojskowa, Kraków 2008.

Gancarson J., Polonica w Zbiorze Autografów Piotra Dubrowskiego (Fond 971) w Rosyjskiej Bibliotece Narodowej w St. Petersburgu, „Teki Sejmowe” 2011, t. 2, s. 7-47.

Gaziński R., Die Kaperflotte von Iwan IV. dem Schrecklichen im Lichte von Akten des Herzoglich Stettiner Archiv, „Studia Maritima” 2013, R. 26, s. 29-37.

Gąsiorowski A., Itineraria dwu ostatnich Jagiellonów, „Studia Historyczne” 1973, R. 16, z. 2, s. 249-275.

Grala H., Dyplomacja z upominkami w tle (Wokót ceremoniatu dyplomatycznego w stosunkach polsko-moskiewskich XVI-XVII w.) [w:] Skarby Kremla. Dary Rzeczpospolitej Obojga Narodów. Wystawa ze zbiorów Państwowego Muzeum Historyczno-Kulturalnego „,Moskiewski Kreml”, Warszawa 1998.

Grala H., Polscy historycy $i$ archiwiści w carskim Petersburgu (tekst wystąpienia wygłoszonego podczas Międzynarodowej Konferencji „Polski Petersburg - historia i pamięć”, zorganizowanej w Sankt Petersburgu w dniach 10-14 kwietnia 2013 r. przez Rosyjskie Państwowe Archiwum Historyczne i Międzynarodowe Centrum Kultury w Krakowie), http://www.polskaipetersburg.pl/images/upload/biblioteka/Polscy_historycy_i_ archiwisci_w_carskim_Petersburgu_Hieronim_Grala.pdf (dostęp: 18.06.2017).

Grala H., Upadek ,, moskiewskiego kanclerza”. Iwan Wiskowaty i Iwan IV w 1570 r., „Kwartalnik Historyczny" 1994, R. 101, z. 1, s. 49-79.

Instrukcja wydawnicza dla źródet historycznych od XVI do połowy XIX wieku, red. K. Lepszy, Wrocław 1953.

Janicki M., Jaworski R., Nad nowa edycją listów króla Zygmunta Augusta, „Przegląd Historyczny" 1999, R. 90, z. 3, s. 347-364.

Jasnowski J., Chodkiewicz Grzegorz, PSB, t. III, Kraków 1937, s. 358-359. 
Jaworski R., Nieznana korespondencja króla Zygmunta Augusta z Mikołajem Radziwittem Rudym i Ostafim Wołlowiczem z lat 1550-1571 ze zbiorów Biblioteki Czartoryskich, „Studia Źródłoznawcze” 2003, t. 41, s. 91-108.

Jaworski R., Z najdawniejszych dokumentów do dziejów domeny Radziwiłlowskiej, „Studia Źródłoznawcze” 2001, t. 39, s. 101-114.

Kamieniecki W., Straty Biblioteki Ordynacji Zamojskich w zakresie zbiorów rękopiśmiennych [w:] Straty archiwów i bibliotek warszawskich $w$ zakresie rękopiśmiennych źródel historycznych, t. III: Biblioteki, Warszawa 1955, s. 143-176.

Kaniewska I., Sawicki Maciej, PSB, t. XXXV, Kraków 1994, s. 334-336.

Katalog dokumentów tureckich. Dokumenty do dziejów Polski i krajów ościennych $w$ latach 1455-1672, oprac. Z. Abramowicz, red. A. Zajączkowski [= Katalog rękopisów orientalnych w zbiorach polskich, red. S. Strelcyn, współudz. M. Lewicki, A. Zajączkowski, t. 1, cz. 1], Warszawa 1959.

Krakowski B., Kajetan Kwiatkowski, PSB, t. XVI, Wrocław 1971, s. 358.

Lepszy K., Haraburda Michat, PSB, t. IX, Warszawa 1960-1961, s. 288-290.

Lachowicz S.A., Listy oryginalne Zygmunta Augusta do Mikołaja Radziwitła Czarnego, Wilno 1842.

Lachowicz S.A., Materiaty historyczne spisane z autentyków Biblioteki Cesarskiej w Petersburgu, „Atheneum” 1842, R. 5, nr 1, s. 28-54.

Listy emigracyjne Joachima Lelewela, wyd. i wstęp H. Więckowska, t. 4 (1849-1861), Wrocław-Kraków 1954.

Listy króla Zygmunta Augusta do Radziwittów, oprac., wstęp i komentarze I. Kaniewska, Kraków 1998.

Listy polskie XVI wieku, t. 2, red. K. Rymut, Kraków 2001.

Lulewicz H., Daremny trud edytora? Uwagi na marginesie edycji korespondencji ostatniego Jagiellona, „Odrodzenie i Reformacja w Polsce” 2000, R. 44, s. 177-185.

Lulewicz H., Radziwitt Mikołaj zwany Rudym, PSB, t. XXX, Wrocław 1987, s. 321-325.

Natanson Leski J., Dzieje granicy wschodniej Rzeczypospolitej, cz. I: Granica moskiewska w epoce jagiellońskiej, „Rozprawy Historyczne Towarzystwa Naukowego Warszawskiego", t. 1, z. 3, Lwów-Warszawa 1922.

Niemcewicz J.U., Zbiór pamiętników historycznych o dawnej Polszczę, t. 1, Warszawa 1822.

Plewczyński M., Wojny i wojskowość polska w XVI wieku, t. 2: Lata 1548-1575, Warszawa 2012.

Przezdziecki A., Jagiellonki polskie w XVI wieku, t. 1, Kraków 1868.

Pułaski F., Nieznane listy Barbary Radziwitłówny do Mikołaja Radziwiłła Rudego $i$ do Zygmunta Augusta, Warszawa 1906.

Pułaski F., Opis 815 rękopisów Biblioteki Ordynacji Krasińskich, Warszawa 1915.

Ragauskienè R., Ragauskas A., Barboros Radvilaitès laiškai Žygimantui Augustui ir kitiems : studija apie XVI a. Lietuvos Didžiosios kunigaikštystès moteru korespondencija, Vilnius 2001.

Stasiewski W.B., Magnus [w:] Neue Deutsche Biographie, Bd. 15, Berlin 1987, s. 865-866. Tchórzewska-Kabata H., Ocalone dla potomnych. Serie wydawnicze Biblioteki Ordynacji Krasińskich. Propozycja badawcza, „Rocznik Biblioteki Narodowej” 2004, 34, s. 79-82. Urzędnicy centralni i dostojnicy Wielkiego Księstwa Litewskiego XIV-XVIIII w. Spisy, oprac. H. Lulewicz, A. Rachuba, Kórnik 1994.

Vetera monumenta Poloniae et Lithuaniae gentiumque finitimarum historiam illustrantia; maximam partem nondum edita ex tabulariis Vaticanis deprompta collecta ac serie 
chronologica disposita T.2 ab Ioanne PP. XXIII. usque ad Pium PP. V. 1410-1572, Romae 1861.

„, Vypiska iz posolskich knig” o snošenijach Rossijskogo gosudarstva s Polsko-Litovskim za 1547-1572 gg. [ = Pamjatniki istorii Vostočnoj Evropy. Istočniki XV-XVII v.t. 2], MoskvaVaršava 1997.

Wasilewski T., Korsak Borkołab Glębocki, PSB, t. XIV, Wrocław 1968-1969, s. 103-104. Wawrzyńczyk A., Studia z dziejów handlu Polski z Wielkim Księstwem Litewskim i Rosja w XVI wieku, Warszawa 1956.

Wiśniewski J., Zbiory archiwalne polskich bibliotek fundacyjnych XIX w., „Poznański Rocznik Archiwalno-Historyczny" 2003/2004, 10/11, s. 87-110.

Żelewski R., Dyplomacja polska w latach 1506-1572 [w:] Historia dyplomacji polskiej, t. 1: Polowa $X-1572$, red. M. Biskup, Warszawa 1980. 